\title{
DISTRIBUTION OF DINOCYSTS IN THE SURFACE SEDIMENTS OF SIDI MOUSSA LAGOON : (ATLANTIC COAST-MOROCCO)
}

\author{
Karima Chaira ${ }^{1-3}$, Btissam Ennaffah ${ }^{2}$, Fatima Zohra Bouthir ${ }^{1}$, Hinde Abdelouahab ${ }^{1}$, et Hassan Rhinane ${ }^{3}$ \\ ${ }^{1}$ Institut National de Recherche Halieutique -Casablanca, Maroc \\ 2 Pôle santé/CIAM/ Université Mohammed VI Polytechnique -Benguerir, Maroc \\ ${ }^{3}$ Laboratoire des Géosciences, Département de géologie, Faculté des Sciences, Université Hassan II, Casablanca, Maroc \\ *corresponding author, e-mail: chairakarima@gmail.com
}

Commission 4, WG 7

KEY WORDS: Sidi Moussa lagoon, cyst abundance, Atlantic coast, toxic species.

\begin{abstract}
The Sidi Moussa lagoon, $\left(32^{\circ} 52\right.$ ' 0 ' 'N / $\left.8{ }^{\circ} 51^{\prime} 05^{\prime} \mathrm{W}\right)$ is located on the Moroccan Atlantic coast between the cities of El Jadida and Safi about $15 \mathrm{~km}$ South of the Jorf Lasfar industrial complex, The climate of the lagoon is classified as hot temperate. It is characterised by an oceanic influence. This study of dinoflagellate cyst mapping is the first of its kind from the Sidi Moussa lagoon. the objectives of the present survey were (i) to evaluate to the spatial variation of dinoflagellate cyst assemblages in the sediment along the Sidi Moussa lagoon (ii) to assess the densities of its cysts (iii) to compare the cyst assemblages in this study with that of other sites. The data were collected in a scientific campaign by zodiac carried out from in April 2018 by core following a sampling network of 21 stations distributed randomly in the study area. The surface layer of the sediment cores $(3 \mathrm{~cm})$ was sliced and kept at $4^{\circ} \mathrm{C}$ until analysis. The highest total cyst abundance was 194 cysts. $\mathrm{g}^{-1}$ dry sediment. The Pearson statistical test revealed a positive and significant correlation between cyst abundance and water content, organic matter and of fine sediment. Our study showed the presence of morphotypes of potentially toxic species. The cysts of these species present in the sediment of the Sidi Moussa lagoon could germinate, when environmental conditions become favorable, and in turn could inoculate the water column with the subsequent bloom formation. This study confirms the usefulness of cyst analysis in the assessment of harmful bloom risk in this area important for oyster's culture.
\end{abstract}

\section{INTRODUCTION}

Cyst formation plays an important role in the genetic structure and ecology of dinoflagellate populations (Anderson \& Wall 1978 ; Dale 1983). As they are able to be preserved in the sediment for long periods of time, dinocysts can potentially constitute a reservoir of diversity (Belmonte et al. 1997).Approximately 200 modern marine dinoflagellate species produce organic walled and calcareous cysts at some point during their sexual or asexual life cycle (Head, 1996). In some toxic dinoflagellate species (e.g. Alexandrium), cysts contain more toxins than their vegetative counterparts (Oshima et al., 1992). Similarly, the transfer of resting stages of the toxic dinoflagellates may contaminate previously unaffected coastal regions.

The Sidi Moussa Lagoon is located on the Atlantic Ocean coast of Morocco. It is considered to be the most productive Moroccan lagoon. Bennouna ,2000) and Daghor et al. (2015) showed that diatoms formed the most dominant phytoplankton taxon in Sidi Moussa Lagoon, followed by dinoflagellates. The high-energy hydrodynamics and shallow depth of the lagoon favour a homogenous distribution of phytoplankton species both vertically and horizontally (Bennouna et al. 2000). Several potentially harmful phytoplankton species of the genera Alexandrium, Prorocentrum and Dinophysis have been identified. Bennouna et al. (2002) reported a red tide of Lingulodinium polyedrum along the Moroccan Atlantic coast in July 1999, including in Sidi Moussa Lagoon. Also known as Lingulodinium machaerophorum, this dinoflagellate species is known to produce cysts (Lewis and Burton 1988). To our knowledge no study dealing with cyst distribution has been carried out on the North African Atlantic coast. Only one study, using palynological methods and involving a limited number of stations, has been conducted on dinoflagellate cysts in Sidi Moussa Lagoon (Daghor et al. 2016).

The main objectives of our study were: (i) to assess the diversity of dinoflagellate cysts in Sidi Moussa Lagoon; (ii) to determine the distribution of these cysts in the sediment of this lagoon; and (iii) to establish potential correlations of cyst densities with the main sediment characteristics, including water percentage, organic matter content and grain size.

\section{MATERIALS AND METHODS}

\subsection{Study area}

The Sidi Moussa lagoon $\left(\left(32^{\circ} 52\right.\right.$ ' 0 ' 'N / $8^{\circ} 51^{\prime} 05$ " W) is a marginal system with a surface area of $4.200 \mathrm{~km}^{2}$, lo-cated in the southern part of the middle of the Atlantic coast of Morocco. The climate of the lagoon is classi-fied as hot temperate. It is characterised by an oceanic influence. In geomorphologic terms, it belongs to an occidental coastal basin called the Sahel. This basin is made up by the morphology of a depression limited by a Plio-Quaternary continental cli and by a coastal consolidated dune ridge in a southwest-northeast direc-tion; it is characterised mainly by yellow detrital lime-stone, formed of shelly sands (Carruesco,1989). 


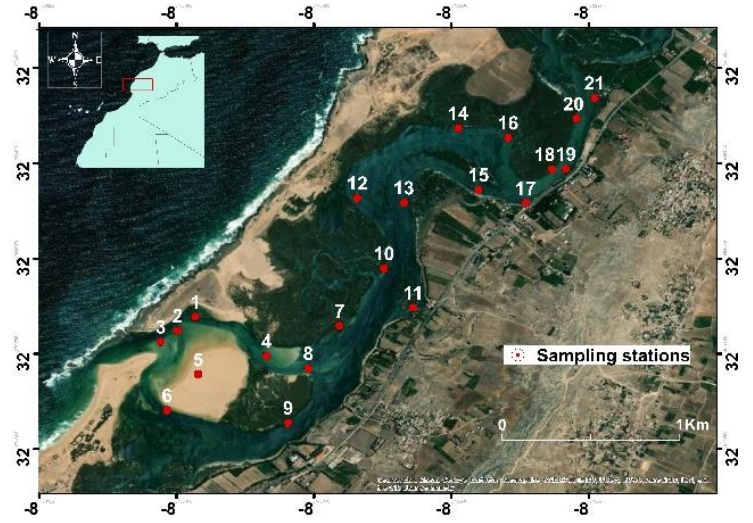

Figure 1. Location of sampling stations in Sidi Moussa Lagoon

\subsection{Environmental parameters}

Physicochemical parameters of the water column, including temperature $\left({ }^{\circ} \mathrm{C}\right)$, salinity, $\mathrm{pH}$ and dissolved oxygen (mg 1-1), were measured at a depth of $0.5 \mathrm{~m}$ using a multiparameter probe (Hanna HI9829). The concentrations of nitrites, nitrates and phosphates were determined by chemical dosage according to the method of seawater analysis reported in (Amino \& Chaussepieds 1983).

\subsection{Sediment characteristics}

Water content $(\% \mathrm{H} 2 \mathrm{O})$ was determined after drying sediment subsamples of $20 \mathrm{~g}$ at $100{ }^{\circ} \mathrm{C}$ for 7 days until all the water was evaporated. To determine the organic matter content (\%OM) of the sediment, subsamples of $20 \mathrm{~g}$ dry weight (Wd) were dried at $450{ }^{\circ} \mathrm{C}$ for $12 \mathrm{~h}$ and the new dry weight (Wd1) was recorded. For grain-size analyses, $100 \mathrm{~g}$ of sediment sample from each of the 51 stations was dried at $40{ }^{\circ} \mathrm{C}$ for $48 \mathrm{~h}$ and then sieved through different meshes $(<63 \mu \mathrm{m}, 63 \mu \mathrm{m}-2 \mathrm{~mm},>2 \mathrm{~mm})$. Grain-size distribution was obtained using the method of Bellair and Pomerol (1977).

\subsection{Sediment sampling and resting cysts extraction}

Sediment sampling was undertaken by a diver using a cylindrical plastic corer ( $47 \mathrm{~cm}$ long, $5 \mathrm{~cm}$ wide). The sediment was sampled at the 21 stations with three replicates at each station. The surface layer $(3 \mathrm{~cm})$ of each sediment core was sliced and kept at $4{ }^{\circ} \mathrm{C}$ in the dark until analysis. For quantification, dinoflagellate resting cysts were separated from $1 \mathrm{~g}$ of sediment sample using a gradient density method with Ludox CL-X colloidal silica (Sigma-Aldrich), according to (Blanco, 1986) and as described in Genovesi et al. (2007) and Yamaguchi et al. (1995). Aliquots ( $1 \mathrm{~g}$ of wet sediment) were suspended in $20 \mathrm{ml}$ of $24 \%$ sucrose solution and sonicated for $3 \mathrm{~min}$ at $100 \mathrm{~Hz}$. The suspension was sequentially sieved through an $80-\mathrm{mm}$ and a $20-\mathrm{mm}$ mesh. The slurry remaining in the $20-\mathrm{mm}$ mesh was washed with sucrose solution and placed in a 15-ml Falcon tube for further sonification $(3 \mathrm{~min}$ at $100 \mathrm{~Hz}$ ). It was then processed for cyst concentration and separated from the sediment using $20 \mathrm{ml}$ of Ludox CL-X (density $1.3 \mathrm{~g} \mathrm{~cm}-3$ ). The tube was centrifuged for $30 \mathrm{~min}$ at $3000 \mathrm{rpm}$, at $4{ }^{\circ} \mathrm{C}$. Resting cysts were concentrated in the upper fraction. This unstable phase containing resting cysts was extracted and sieved through a $20-\mathrm{mm}$ nylon membrane. The resulting sample was rinsed with seawater and collected with 5 $\mathrm{ml}$ of filtered seawater. Cysts were identified using an inverted photonic microscope (Leica DM IRB).

\subsection{Phytoplankton in the water column}

Seawater samples from the water column were collected during high tide using polyethylene bottles. Samples were fixed with neutralised formalin to a final concentration of $4 \%$. The samples were left to settle for $24 \mathrm{~h}$ according to the Utermöhl method (Utermöhl 1958). Species identification and enumeration were carried out using an inverted microscope (Nikon Eclipse TS100).

\subsection{Statistical analyses}

A Principal Component Analysis (PCA) is performed using XLStat 2018.6 for Windows on standardized data, whose objective is to relate the resting cysts distribution pattern to environmental variables.

\section{RESULTS}

\subsection{Physicochemical parameters and sedimentological characteristics}

The average water temperature calculated from the 21 stations surveyed during the study period (January 2018) was $15.53 \pm 0.16$ ${ }^{\circ} \mathrm{C}$, with a maximum of $16{ }^{\circ} \mathrm{C}$, reported at station 17 , and a minimum of $15.3{ }^{\circ} \mathrm{C}$ recorded in station 13 (Fig.2.). The fluctuations of salinity in the lagoon were directly related to sealagoon exchanges, and to the inflow of fresh water through the three seasonal rivers. The average salinity of the water was 28,96 \pm 3.65 . The maximum salinity of 31,55 was recorded at station 3 in the south of the lagoon, while the minimum salinity of 20,17 was detected at station 20 at the extreme north of the lagoon far from marine influences (Fig.2). The $\mathrm{pH}$ of the waters of the lagoon was slightly alkaline and oscillated between 8.38 and 8.7. In addition, the waters of the Sidi Moussa lagoon were well oxygenated; particularly with regard to the peripheral stations and the contents vary between 5 and 7.65 mg.L -1 (Fig.2.).

Particle-size analysis revealed three types of sediment facies: sandy mud, muddy sand and sand. The fine fraction $(<63 \mu \mathrm{m})$ ranged from $1 \%$ to $73 \%$ at St2 and St7, respectively (Figure 3). Water percentages of sediment samples were heterogeneous $(41.73 \pm 14.20)$ and peaked with a maximum of $69.01 \%$ at St 19 (Fig 4A). Organic matter contents ranged from 1.93 to $13.08 \%$, showing maxima in the center and in the north the lagoon (Fig $4 b)$.

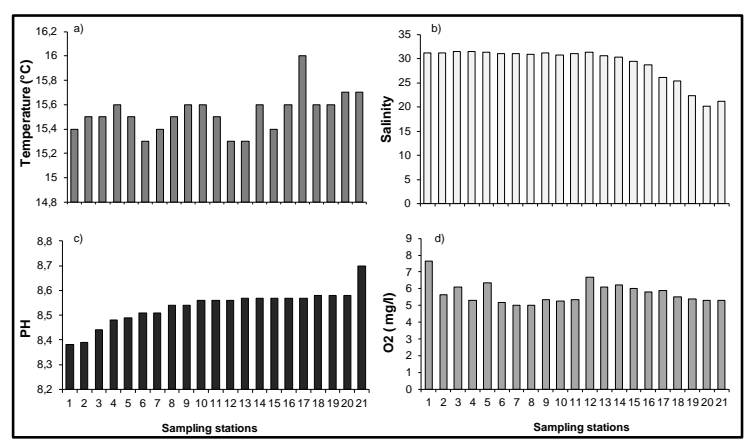

Figure 2. Spatial distribution of Physicochemical parameters 


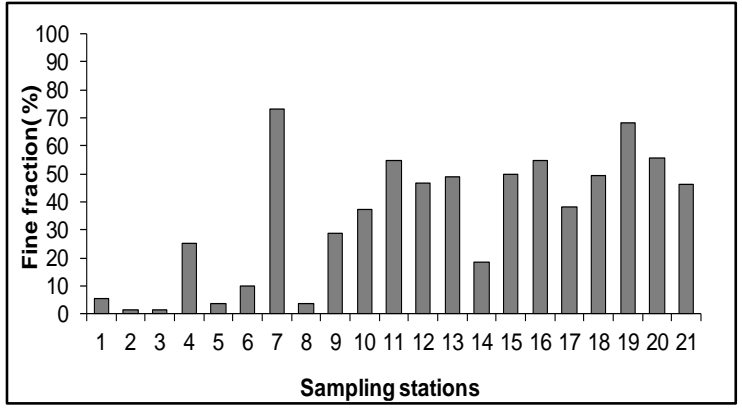

Figure 3. Spatial distribution of fine fraction

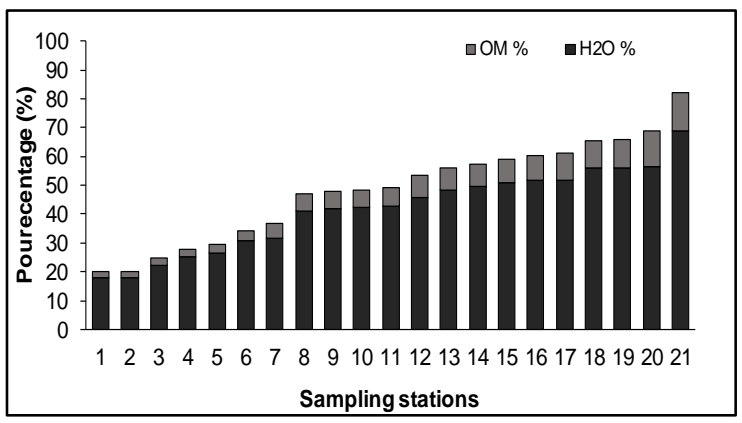

Figure 4. Water and organic matter content of sediments expressed in percentage

\subsection{Dinocysts distribution and abundance}

At least 18 morphotypes were identified in the surface sediment of sidi Moussa Lagoon spread over three orders, namely Gonyaulacales (Alexandrium minutum, the Alexandrium tamarense species complex [including A. catenella and A. tamarense, which are cryptic species that are barely distinguishable on the basis of morphological examination of their resting cysts], Lingulodinium polyedrum, the Gonyaulax cf. spinifera complex, the Gonyaulax digitalis and Gonyaulax spp.), Peridiniales (Protoperidinium oblongum, Protoperidinium conicum and Protoperidinium pentagonum) and Gymnodiniales (Gymnodinium catenatum, Polykrikos kofoidi and Polykrikos schwartzii) ( supplementary data 1). Dinoflagellate cysts accumulated in the surface sediment across the whole lagoon and showed different densities according to geographical location. The highest cyst density (194 cysts $\mathrm{g}^{-1} \mathrm{DS}$ ) was recorded at St 7 located 7 in the inner part of the lagoon and the lowest concentration ( 0 cysts $\left.\mathrm{g}^{-1} \mathrm{DS}\right)$ was recorded at downstream of the lagoon. The cyst assemblage was dominated by L. polyedrum $(62.36 \%)$ and polykrikos kofoidi. (7.16\%) (Fig.5.). Five morphotypes related to potentially noxious/toxic species were found in surface sediment, namely the $G$. cf. spinifera complex, A. minutum, the A. tamarense species complex, G. catenatum and L. polyedrum (Figure 6).

\subsection{Relationship between environmental factors and resting cysts abundance}

Pearson correlations (Figure 7) revealed a significant positive relationship between the density of dinoflagellate cysts, \% OM $(r$ $=0.44, p<0.05), \% \mathrm{H}_{2} \mathrm{O}(r=0.43, p<0.05)$ and the fine fraction $(\leq 63 \mu \mathrm{m})(r=0.54, p<0.05)$. In addition, no significant correlation was observed between cyst density and the measured physicochemical parameters in the water column (temperature, salinity, $\mathrm{pH}, \mathrm{O}_{2}$, nutrients).

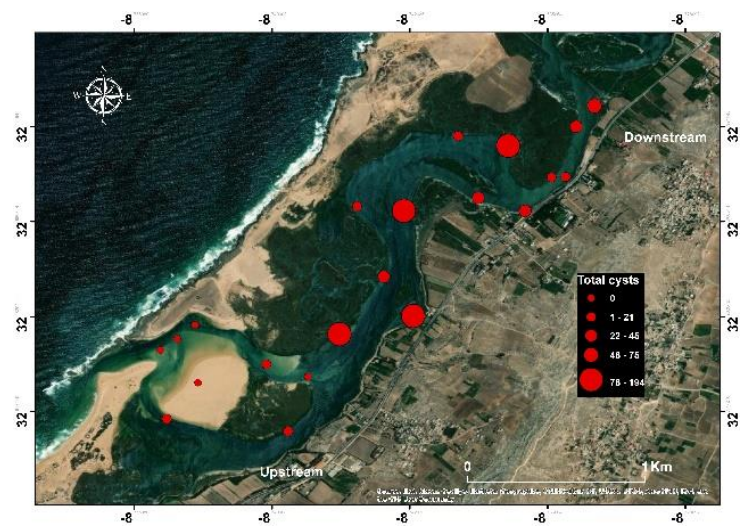

Figure 5. Spatial distribution (21 stations) of dinoflagellate cysts (cysts $\mathrm{g}-1$ dry sediment) in sediments of Sidi Moussa Lagoon

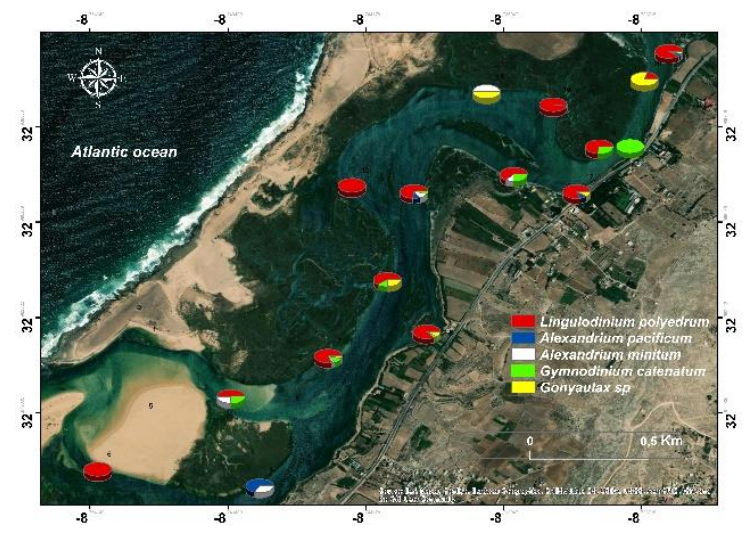

Figure 6. Distribution (\%) of cysts of the major potentially harmful dinoflagellate species recorded in the sediments of Sidi Moussa Lagoon

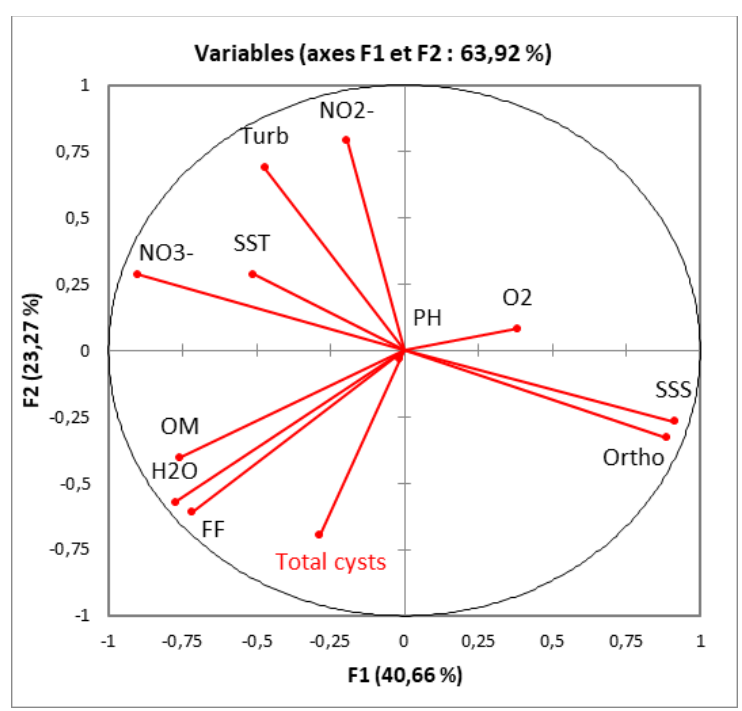

Figure7. Principal components analysis plot showing the positive correlations between dinoflagellate cyst density and organic matter content $(\% \mathrm{OM})$, water content $(\% \mathrm{H} 2 \mathrm{O})$, and fine fraction $(\mathrm{FF})$ of the sediment. There was no signification correlation with nutrients, water temperature (SST), salinity

(SSS), Turbidty(turb), $\mathrm{pH}$ or dissolved oxygen (O2) 


\subsection{Phytoplankton species and abundance observed in the} water column

The microphytoplankton community consisted of only three groups, with 20 diatom species forming the most dominant taxa (Fig.8), followed by dinoflagellates, Euglenophyceae and finally Euglenophyceae. The inventory of dinoflagellates revealed 14 species: Alexandrium sp., Lingulodinium polyedrum, Gymnodinium catenatum, Dinophysis sp Scrippsiella trochoidea, Karenia sp., Scrippsiella sp., Ostreopsis sp., Prorocentrum minimum, Prorocentrum scutellum, Prorocentrum micans, Prorocentrum sp, Gyrodinium spirale. and Gymnodinium sp

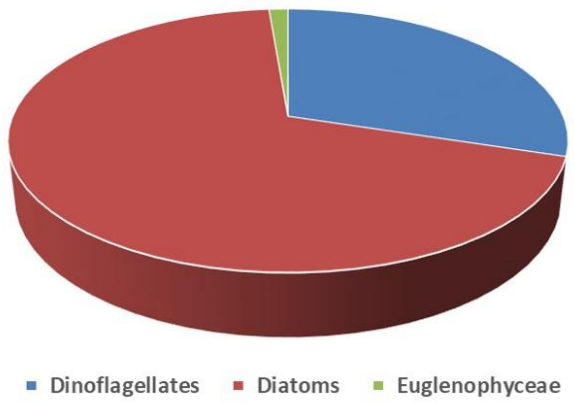

Figure 8. Groups of phytoplankton

\section{DISCUSSION}

Cyst assemblages have been poorly studied in North African Atlantic waters including Moroccan marine ecosystems. The only studies to have investigated dinoflagellate cysts (Chaira et al.,2021) in Oualidia lagoon and (Daghor et al. 2016), did so at only four stations in Sidi Moussa Lagoon and used a palynological method. This study showed that the assemblages of dinoflagellate cysts in this lagoon were dominated by Lingulodinium polyedrum (L. machearophorum). Our study also showed that L. polyedrum dominated the dinoflagellate cysts found in the sediment of Nador Lagoon, Morocco (western Mediterranean Sea) (Daghor et al., 2016) and Oualidia lagoon (Chaira et al., 2021).In addition, our results confirm the usefulness of cyst studies in identifying the potentially harmful Alexandrium tamarense species complex, A. minutum and Gymnodinium catenatum, which may be responsible for paralytic shellfish poisoning (PSP) events, together with Gonyaulax spinifera and L. polyedrum, which are both known to be associated with harmful events (Bennouna et al. 2002), because the cysts of these species were found in the sediment of Sidi Mousa Lagoon. This finding corroborates previous reports (Bennouna 2000, 2002; Daghor et al.,2015) on the phytoplankton community of the Sidi Moussa water column which showed the presence of the cited HAB species. In the present study, L. polyedrum was the most abundant cyst morphotype found in the sediment (153 cysts g-1 DS at Station 7). This finding is in accordance with several studies (Bennouna et al. 2002 ; Ennaffah 2005) that showed that this dinoflagellate regularly forms red tides in Sidi Moussa Lagoon, with high biomasses of $7.910^{4}$ cells $1-1$ reported in 1999 and 2005, respectively. Our data on the distribution of cysts helps to explain the recurrent blooming of some dinoflagellate species, such as L. polyedrum, in Sidi Moussa Lagoon.

The spatial distribution of cysts revealed that they accumulated preferentially in the central region and the upper region of the lagoon. Stations 7,11,13 located in the inner lagoon, and Station 16 in the north of the lagoon near clam farm, showed the highest cyst densities, reaching 194 cysts g-1 DS ,164 cysts g-1 DS , 162 cysts g-1 DS and 148 cysts g-1 DS, respectively. Cyst densities in this unique preserved ecosystem are characterised by moderate values (up to 194 cysts.g -1 DS) compared with different lagoons and bays across the world. Indeed, the found cysts densities are lower than those reported in Oualidia lagoon (Morocco) with up to 293 cysts.g -1 DS (Chaira et al.,2021), in Mellah lagoon (Algeria) with up to 315 cysts $\mathrm{g}^{-1}$ DS (Draredja et al., 2020) in the Bizerte lagoon (Tunisia), with up to 20,126 cysts.g -1 DS (Fertouna-Bellakhal et al., 2014) and 2,742 cysts.g-1 DS (Zmerli Triki et al., 2017), in Izmir Bay (Turkey) up to 3,292 cysts.g -1 DW (Aydin et al., 2011), in Cabras in Sardinia (Italy) up to 287 cysts g -1DW (Setta et al., 2014). However, the cyst abundances of Sidi Moussa lagoon are higher than those found in Homa Lagoon (Turkia) up to 71 cysts.g -1 DW (Aydin et al., 2014), in Thailand and Malaysia up to 12-56 cysts'g-1 DW (Lirdwitayaprasit ,1997) and Boughrara Lagoon (Tunisia), with up to 132 cysts $\mathrm{g}^{-1}$ DS (Abdmouleh Keskes et al., 2020)

This is the first study reporting the presence of the cysts of the potentially neurotoxic Alexandrium , which were observed at nine stations in Sidi Moussa Lagoon (Stations 4, 7, 9, $13,14,15,16,17$ and 21). In addition, our results confirm the usefulness of cyst studies in identifying the potentially harmful Alexandrium tamarense species complex, A. minutum and Gymnodinium catenatum, which produces Paralytic Shellfish Toxins (PSTs) (Anderson et al. 2012).

Despite its historical high anthropo- genic characteristic (Benmhammed et al.,2021; Cheggour et al., 2001; El himer et al.,2013), this un- expected low abundance of cysts in Sidi Moussa Lagoon could be explained by the sampling period coinciding with a bloom, and is likely justified by cysts germination and/or an absence of cysts bank. The reduced number of morphotypes could also be explained by the weak presence of phytoplankton, especially dinoflagellates, in the water column (Bennouna et al.,2002; present study) dominated by Perdinium quinquecorne and kryptoperidinium foliaceum (Daghor et al., 2015)

The abundance of dinoflagellate cysts was positively correlated with the main sediment characteristics of Oualidia Lagoon. The highest cyst densities were found in muddy sediments $(<63 \mu \mathrm{m})$ with high $\mathrm{H}_{2} \mathrm{O}$ and $\mathrm{OM}$ contents. In fact, dinoflagellate cysts behave as fine particles (Larrazabal, 1987). Our results corroborate those of several studies (Yamaguchi et al., 1996; Gayoso 2001; Matsuoka et al., 2003; Joyce et al. 2005; Anglès et al. 2010; Horner et al. 2011; Genovesi et al., 2013) that have shown that accumulation of dinoflagellate cysts occurs in muddy sediments containing a high proportion of organic matter. The hydrodynamics of Sidi Moussa Lagoon may play an important role in the distribution of dinoflagellate cysts. (El khalidi et al.,2003) highlighted three separate zones: a downstream lagoon zone subject to marine influences, an intermediate zone where the influence is twice as strong and a confined zone characterised by a weak hydrodynamic regime located at the upstream end of the lagoon. The dinoflagellate cyst abundance reported in sediment of Sidi Moussa Lagoon was low to moderate. The permanent resuspension of the superficial sediment and transportation of sediment due to tidal currents in the shallow water column can spread cysts, even to the open ocean, potentially causing the contamination of other Atlantic coastal areas. 
In turn, a reduction of the dinoflagellate cysts abundance in the water column is caused by the sedimentation through adsorption into organic and mineral supplies (Wang et al., 2004). Indeed, high sedimentation rate combined with the presence of muddy fraction promotes resting cyst, thus burying cysts (Godhe and McQuoid, 2003) and decreasing their abundance. High sedimentation rates have been recorded in ecosystems characterized by high cysts abundance. For example, the sedimentation rate varies between 0.16 and $0.33 \mathrm{~cm}$ year in the Thau Lagoon (French Mediterranean coast) (Elbaz-Poulichet et al., 2005) and it reaches $2.0 \mathrm{~cm}$ year in Manila Bay (Philippines) (Sombrito et al., 2004). It ranges from 0.37 to $2.44 \mathrm{~cm}$ year in ghar elmaleh lagoon. (Tunisia) (Dhib, 2015), in where the number of cyst varies between 0 and 194 cysts.g In Sidi Moussa Lagoon, It is 0,64 cm/an (Maanan, 2003).

\section{CONCLUSION}

The spatial distribution of cysts may be influenced by sediment characteristics and hydrodynamic features. Statistical analyses showed positive correlations between the mud fraction, water content and organic matter content of sediments with cyst densities. Cyst density was higher upstream where the hydrodynamic regime is relatively weak, facilitating the deposition of cysts. Mapping cysts may be of help in selecting sites for future aquaculture activities and better implementation of sediment dredging operations to prevent the spread of these resting cells, because sediments can be loaded with cysts of toxic species. Likewise, monitoring programmes should include cyst population studies for early detection of potential HAB risks to protect human health and prevent economic losses on aquaculture farms.

\section{ACKNOWLEDGEMENTS}

We thank the Moroccan National Institute of Fisheries Research (Institut National de Recherche Halieutique, INRH), We are grateful to the INRH monitoring team at Oualidia, for helping us during sampling and.

\section{REFERENCES}

Abdelmouleh keskes F,Mahfoudi M, Abdennadher M, Dammak Walha L, Ben Ismail S, Ben Abdallah O, Khammeri Y, Pagano M, Hamza A, Bel Hassen M, 2020. Dinoflagellates encystment with emphasis on blooms in Boughrara Lagoon (South-Western Mediterranean): Combined effects of trace metal concentration and environmental context. Estuarine, Coastal and Shelf Science. 237,106648 .

Aminot A, Chaussepied M. 1983. Manuel des analyses chimiques en milieu marin. Brest, France: CNEXO

Anderson D.M., Wall D. (1978) Potential importance of benthic cysts of Gonyaulax tamarensis and G. excavata in initiating toxic dinoflagellate blooms. Journal of Phycology, 14 (2), 224-234.

Anderson DM, Alpermann TJ, Cembella AD, Collos Y, Masseret E, Montresor M (2012) The globally distributed genus Alexandrium: multifaceted roles in marine ecosystems and impacts on human health. Harmful Algae 14: 10-35

Anglès S, Jordi A, Garces E, Basterretxe G, Palanques A. 2010. Alexandrium minutum resting cyst distribution dynamics in a confined site. Deep-Sea Research Part II: Topical Studies in Oceanography 57: 210-221.
Bellair P, Pomerol C. 1977. Eléments de géologie. Paris: Armand Colin.

Belmonte G, Miglietta A, Rubino F, Boero F. 1997. Morphological convergence of resting stages of planktonic organisms: a review. Hydrobiologia 355: 159-165

Benmhammed A., Laissaoui A., Mejjad N., Chakir E M., Zia, N., Benkdad,A., ... \& Bouh, H. A. (2021). Assessment of Chronological Records of Rare Earth Elements in Sidi Moussa Lagoon Sediment (North-Western Morocco).

Bennouna A, Berland B, El Attar J, Assobhei O. 2000. Étude des populations phytoplanctoniques de la lagune d'Oualidia (Maroc), dinoflagellés potentiellement nuisibles. Marine Life 10: 3-18.

Bennouna A, Assobhei O, Berland B, El Attar J. 2002. Eau colorée à Lingulodinium polyedrum, incidence sur des sites aquacoles du littoral du Doukkala (Maroc). Oceanologica Acta 25: 159

Blanco J. 1986. Separacion de quistes de dinoflagelados en gradiante de densidad. Oceanography 3: 181-184.

Carruesco C. 1989. Genèse et évolution à l'holocène de trois lagunes de la façade Atlantique: Moulay Bousselham, Oualidia (Maroc) et Arcachon (France). Thèse Doctorat d'Etat, Université Bordeaux I, France.

Chaira K, Rhinane H, Ennaffah B, Maimouni S, Sagou R, Loulad S, BenMhamed A, A Agouzouk A, S BenBrahim S, Masseret E \& Laabir M (2021) The distribution of dinoflagellate cyst assemblages in recent sediments of the Oualidia Lagoon, Morocco, with a focus on toxic species, African Journal of Marine Science, 43:3, 279-292, DOI: 10.2989/1814232X.2021.1945684.

Cheggour M., Chafik A., Langston W. J., Burt G. R., Benbrahim S., \& Texier, H. (2001). Metals in sediments and the edible cockle Cerastoderma edule from two Moroccan Atlantic lagoons: Moulay Bou Selham and Sidi Moussa. Environmental Pollution, 115(2), 149-160.

Daghor, L., Hssaïda, T., Fraikech, M., Ennaffah, B., Bouthir, F. Z., Mimouna, A., \& El Bouhmadi, K. (2015). Impact of environmental disturbances on the dynamics of phytoplankton blooms. International Journal of Advanced Research,3(11), 1071-1085.

Daghor L, Hssaïda T, Chakir S, Slimani H, Mouflih M, Hamoumi N et al. 2016. Dinoflagellate cyst study of surface sediments from the Moroccan Atlantic lagoon system OualidiaSidi Moussa and the Mediterranean lagoon of Nador. Bulletin de l'Institut Scientifique, Rabat, Section Sciences de la Terre 38: 118.

Dale B. 1983. Dinoflagellate resting cysts: "benthic plankton". In: Fryxell GA (ed.), Survival strategies of the algae. Cambridge, UK: Cambridge University Press. pp 69-136.

Dhib, A., 2015. Contribution a l'etude des successions ecologiques du phytoplancton dans la lagune de Ghar El Melh. These de doctorat de l'universite de Franche-Comte.

Draredja MA, Frihi H, Boualleg C, Abadie E, Laabir M, 2020. Distribution of dinoflagellate cyst assemblages in recent sediments from a southern Mediterranean lagoon (Mellah, Algeria) with emphasis on toxic species. Environmental Science and Pollution research. 27, 25173- 25185.

Elbaz-Poulichet F, Seidel, JL Jezequel, D, Metzger, E, Prevot, F, Simonucci, C,

Sarazin, G, Violler, E, Etcheber, H., Jouanneau, JM, Weber, O, Radakovitch, O., 2005. Sediment record of redox-sensitive 
elements (U, Mn, Mo) in a transitory anoxic basin (the Thau lagoon, France). Mar. Chem. 95, 271-281

El Himer H, Fakir Y, Stigter T Y, Lepage M, El Mandour A, \& Ribeiro, L. (2013). Assessment of groundwater vulnerability to pollution of a wetland watershed: The case study of the Oualidia-Sidi Moussa wetland, Morocco. Aquatic Ecosystem Health \& Management, 16(2), 205-215.

Ennaffah B. 2005. Sur la surveillance des efflorescences nuisibles au niveau de la frange littorale Essaouira-Azemmour Janvier-Décembre 2004. Rapport interne. Casablanca, Morocco: Institut National de Recherche Halieutique

Fertouna-Bellakhal M, Dhib A, Bejaoui B, Turki S, Aleya L. 2014. Driving factors behind the distribution of dinocyst composition and abundance in surface sediments in a western Mediterranean coastal lagoon: report from a high-resolution mapping study. Marine Pollution Bulletin 84: 347-362

Gayoso AM. 2001. Observations on Alexandrium tamarense (Lebour) Balech and other dinoflagellate populations in Golfo Nuevo, Patagonia (Argentina). Journal of Plankton Research 23 : 463-468.

Godhe A, Mcquoid M, 2003. Influence of benthic and pelagic environmental factors on the distribution of dinoflagellates cysts in surface sediment along the Swedish west coast. Aquat. Microb. Ecol. 32, 185-201.

Genovesi B, Mouillot D, Vaquer A, Laabir M, Pastoureaud A. 2007. Towards an optimal sampling strategy for Alexandrium catenella (Dinophyceae) benthic resting cysts. Harmful Algae 6 : $837-848$

Genovesi B, Mouillot D, Laugier T, Fiandrino A, Laabir M, Vaquer A, Grzebyk D. 2013. Influences of sedimentation and hydrodynamics on the spatial distribution of Alexandrium catenella/tamarense resting cysts in a shellfish farming lagoon impacted by toxic blooms. Harmful Algae 25: 15-25.

Head, M.J., 1996. Modern dinoflagellate cysts and their biological affinities. In: Jansonius, J., McGregor, D.C. (Eds.), Palynology: Principles and Applications, vol. 3. AASP Foundation, Salt Lake City, UT, pp. 1197-1248

Horner RA, Greengrove CL, Davies-Vollum KS, Gawel JE, Postel JR, Cox AM. 2011. Spatial distribution of benthic cysts of Alexandrium catenella in surface sediments of Puget Sound, Washington, USA. Harmful Algae 11: 96-105.

Joyce LB, Pitcher GC, Randt AD, Monteiro PMS. 2005. Dinoflagellate cysts from surface sediments of Saldanha Bay, South Africa: an indication of the potential risk of harmful algal blooms. Harmful Algae 4: 309-318.

Larrazabal ME. 1987. Etude des kystes de dinoflagellés en Baie de Vilaine. Synthèse bibliographique. Rapport DERO-MR. IFREMER: Nantes

Lirdwitayaprasit, T., 1997. Distribution of dinoflagellate cysts in the surface sediment of the South China Sea, Area I: Gulf of Thai- land and East Coast of Peninsular Malaysia. In Proceedings of the First Technical Seminar on Marine Fishery Resources Sur- vey in the South China Sea. Training Department, Southeast Asian Fisheries Development Center, pp. 294309
Maanan M. 2003. Etude sédimentologique du remplissage de la lagune de Sidi Moussa (côte atlantique marocaine) : caractérisations granulométrique, minéralogique et géochimique. Thèse de Doctorat, Université Chouaib Doukkali, Faculté des Sciences El Jadida, Maroc, 172 p.

Matsuoka K, Joyce LB, Kotani Y, Matsuyama Y. 2003. Modern dinoflagellate cysts in hypertrophic coastal waters of Tokyo Bay, Japan. Journal of Plankton Research 25: 1461-1470.

Matsuoka K, Fukuyo Y. 2000. Technical guide for modern dinoflagellate cyst study. Tokyo, Japan: WESTPACHAB/WESTPAC/IOC.

Oshima, Y., Bolch, C.J., Hallegraeff, G.M., 1992. Toxin composition of resting cysts of Alexandrium tamarense (Dinophyceae). Toxicon 20, 1539-1544

Sombrito, E.Z., Bulos, A.D.M., Sta Maria, E.J., Honrado, M.C.V., Azanza, R.V., Furio, E.F., 2004. Application of 210 $\mathrm{Pb}$-derived sedimentation rates and dinoflagellate cyst analyses in understanding Pyrodinium bahamense harmful algal blooms in Manila Bayand Malampaya Sound, Philippines. J. Envrt. Radioact 76, 177-194

Yamaguchi M, Itakura S, Imai I, Ishida Y. 1995. A rapid and precise technique for enumeration of resting cysts of Alexandrium spp. (Dinophyceae) in natural sediments. Phycologia 34: 207-214

Utermöl H. 1958. Zur vervollkomnung der quantitaven phytoplankton-methodik. Internationale Vereinigung für Theoretische und Angewandte Limnologie: Mitteilungen 9: 138 .

Wang Z, Matsuoka K, Qi YZ, Chen JF, Lu SH. 2004. Dinoflagellate cyst records in recent sediments from Daya Bay, South China Sea. Phycol. Res. 52, 396-407.

Yamaguchi M, Itakura S, Nagasaki K, Imai I. 1996. Distribution and abundance of resting cysts of the toxic dinoflagellates Alexandrium tamarense and A. catenella in sediments of the eastern Seto Inland Sea, Japan. In: Yasumoto T, Oshima Y, Fukuyo Y, UNESCO: Intergovernmental Oceanographic Commission (eds), Harmful and toxic algal blooms. Proceedings of the Seventh International Conference on Toxic Phytoplankton, Sendai, Japan, 12-16 July 1995. Paris: IOC of UNESCO. pp 177-180.

Yamaguchi M, Itakura S, Imai I, Ishida Y. 1995. A rapid and precise technique for enumeration of resting cysts of Alexandrium spp. (Dinophyceae) in natural sediments. Phycologia 34: 207-214

Zmerli-Triki H, Laabir M, Lafabrie C, Malouche D, BanconMontigny C, Gonzalez C, Deidun A, Princault O, Kéfi DalyYahi O (2017) Do the levels of industrial pollutants influence the distribution and abundance of 900 dinoflagellate cysts in the recently-deposited sediment of a Mediterranean coastal ecosystem? Sci Total 901 Environ 595: 380-392 